\title{
PENGARUH KONSUMSI EKSTRAK DAUN SAUROPUS ANDROGYNUS (L) Meer (KATU) DENGAN PENINGKATAN HORMON PROLAKTIN IBU MENYUSUI DAN PERKEMBANGAN BAYI DI KELURAHAN WONOKROMO SURABAYA
}

\author{
Siti Nurjanah, Nurul Kamariyah, Umdatus Soleha \\ Fakultas Keperawatan dan Kebidanan \\ Universitas Nahdlatul Ulama Surabaya \\ Email: nungj@unusa.ac.id
}

\begin{abstract}
Abstrack
Breast milk contains more than a hundred kind of nutrient that needed for baby's growth and development. But now theres so many mother that didn't give breast milk because they didn't produce enough. One of the method that can increase the poduction of breast milk is with giving the breast feeding mother katu's leaf. This research head for analyze influence of consumption the leaf of Sauropus Androgynus (L) Merr (Katu) that related with raising prolactin hormones of the breast feeding mother and babies development in Wonokromo Surabaya district.
\end{abstract}

This research is Quasi Experiment research with using the post test-only control group design. The population that being the target for this research is all of the breast feeding mother that consume katu's leaf as many as 18 and 6 people as control. The research unit as many as 24 respondent obtained with using simple random sampling technique. Free variabel is extract of katu's leaf and dependent variabel is prolactin hormones and baby's development. Collect the data with using check list, and examination of blood samples with pra screening of development questionnaire

Result of One Way Anova test between consume katu's leaf extract with the level of prolactin hormones obtained a significant difference $(p=0,000)$. The conclusion of this research is the treatment 2 and 3 have the significant result.

To increase the production of breast milk and baby's development maximally the breast feeding mother be expected to consume the katu's leaf 2 until 3 times a day.

Keywords: Sauropus androgynus Leaves, the hormone prolactin, a baby's development

Abstrak

Air Susu Ibu (ASI) mengandung lebih dari seratus jenis zat gizi yang dibutuhkan untuk pertumbuhan dan perkembangan bayi. Akan tetapi pada saat ini banyak ibu menyusui yang tidak memberikan ASI di karenakan produksi ASI yang tidak mencukupi. Untuk meningkatkan produksi ASI Ibu salah satunya dapat diberikan daun katu. Penelitian ini bertujuan menganalisis Pengaruh Konsumsi Daun Sauropus Androgynus (L) Merr (Katu) dengan Peningkatan Hormon Prolaktin Ibu Menyusui dan Perkembangan Bayi di Kelurahan Wonokromo Surabaya. Penelitian ini merupakan jenis penelitian Quasi Eksperimen dengan rancangan the post test-only control group design. Populasi target adalah seluruh ibu menyusui yang mengkonsumsi daun katu sebanyak 18 orang dan 6 orang sebagai kontrol. Unit penelitian sebanyak 24 responden didapatkan melalui tehnik simple random sampling. Variabel bebas adalah ekstrak daun katu, sedangkan variabel terikat adalah hormon prolaktin dan perkembangan bayi. Pengumpulan data menggunakan ceklist, dan pemeriksaan sampel darah serta kuesioner pra skrining perkembangan (KPSP). Dengan analisis statistik uji One Way Anova.

Hasil uji One Way Anova antara konsumsi ekstrak daun katu dengan kadar hormon prolaktin didapatkan perbedaan yang bermakna $(p=0,000)$. Hasil uji One Way Anova 
antara konsumsi ekstrak daun katu dengan perkembangan didapatkan perbedaan yang bermakna $(p=0,000)$. Simpulan penelitian ini adalah Perlakuan 2 dan 3 mempunyai hasil yang signifikan. Untuk meningkatkan produksi air susu dan perkembangan bayi secara maksimal di harapkan ibu yang menyusui dapat mengkonsumsi ekstrak daun katu sebanyak 2-3 kali sehari.

\section{PENDAHULUAN}

ASI merupakan makanan bayi yang terbaik dan setiap bayi berhak mendapatkan ASI, maka Departemen Kesehatan telah menerbitkan Surat Keputusan Menteri Kesehatan nomer 450/Menkes/SK IV/2004 tentang pemberian Air Susu IBu (ASI) secara eksklusif pada bayi di Indonesia. Makanan yang paling cocok untuk bayi adalah ASI. Di dalam ASI terkandung lebih dari seratus jenis zat gizi yang dibutuhkan untuk pertumbuhan bayi dan tidak dapat disamakan dengan susu jenis manapun (Damayanti, 2010). Komposisi gizi yang terkandung di dalamnya dapat diserap secara sempurna oleh system pencernaan bayi yang masih sangat terbatas kemampuannya (Gibney, 2010). Namun, pemberian ASI kepada bayi tidak bisa dilakukan oleh semua perempuan, karena pengetahuan yang kurang memadai, atau persepsi yang keliru tentang payudara dan menyusui, alasan ASI tidak keluar atau takut payudara rusak, pemahaman yang kurang tentang peran dan fungsi ibu, payudara tidak selalu dilihat sebagai perangkat untuk menyusui anaknya. Akibatnya, ibu akan menggantikan ASI dengan susu formula, ASI menjadi terbuang percuma, dan anak tidak mendapatkan nutrisi dari ibunya yang akan mengakibatkan kekurangan gizi pada anak. Hal ini merupakan pertanda adanya perubahan sosial dan budaya yang berdampak negatif yang dapat mempengaruhi perkembangan bayi dan perkembangan generasi muda di Indonesia. Perkembangan bayi sebagian kecil terjadi keterlambatan, hal ini mungkin dikarenakan bayi tidak diberi ASI secara sempurna dengan alasan sebagian besar ibu bekerja dan harus meninggalkan rumah. Pemberian ASI bukanlah sekedar memberi makanan kepada bayi. Ketika ibu mendekap memberi bayi yang sedang disusukan, pandangan mata ibu tertuju kepada bayi dengan nuansa kasih sayang dan keinginan untuk dapat memahami kebutuhan si bayi. Sikap ibu menimbulkan rasa nyaman dan aman pada bayi, bayi merasa dimengerti, dipenuhi kebutuhannya, disayangi, dan dicintai. Kedekatan ibu dengan bayinya akan memepengaruhi perkembangan psikologi bayi yang akan berdampak pada perkembangan emosional bayi. Dari beberapa pandangan tentang pemberian ASI kepada bayi, akan timbul upaya yang dilakukan oleh ibu-ibu untuk meningkatkan produksi ASI agar air susunya bisa keluar banyak, sehingga dapat mencukupi kebutuhan nutrisi bayi. Upaya yang dilakukan oleh masyarakat untuk meningkatkan produksi ASI adalah dengan cara mengkonsumsi daun Sauropus androgynus (L.) Merr (katu), baik sebagai sayuran atau dalam bentuk ekstrak yang diyakini akan memproduksi ASI. Konsumsi sayuran daun katu membuat ibu kesulitan mencari, mengolah dan konsumsinya, sehingga mereka lebih mudah mengkonsumsi daun katu yang sudah dibuat ekstrak. Hasil penelitian menunjukkan bahwa konsumsi daun katu oleh ibu-ibu menyusui akan meningkatkan waktu menyusui bayi perempuan. Sedangkan pada bayi lakilaki tampak hanya kecenderungan peningkatan frekuensi dan lama menyusui jika mengkonsumsi daun katu. Hal ini menunjukkan bahwa memang mengkonsumsi daun katu dapat meningkatkan produksi air susu ibu. (Kamariyah, 2012). Penelitian lain menyatakan pemberian ektraks daun 
katu pada kelompok ibu melahirkan dan menyusui bayinya dengan dosis $3 \mathrm{x}$ $300 \mathrm{mg} /$ hari selama 15 hari terus menerus mulai hari ke 2 atau hari ke 3 setelah melahirkan dapat meningkatkan produksi ASI $50,7 \%$ lebih banyak dibandingkan dengan kelompok ibu melahirkan dan menyusui bayinya yang tidak diberi ektraks daun katu (Sa'roni, 2004). Peneliti Nurul Kamariyah tahun 2012 membuktikan bahwa pemberian ektrak daun katu 24 dan $48 \mathrm{mg} / \mathrm{kg}$ BB pada tikus akan meningkatkan kadar hormon prolaktin pada induk tikus dan meningkatkan perkembangan sel neuraglia pada anak tikus. Kemampuan memperbanyak air susu berhubungan dengan peranannya dalam refleks prolaktin, yaitu refleks yang merangsang alveoli untuk memproduksi susu. Refleks ini dihasilkan dari reaksi antara prolaktin dengan hormon adrenal steroid dan tiroksin. Daun katu mengandung polifenol dan steroid yang berperan dalam refleks prolaktin. Daun katu kaya akan $\beta$ carotene, maka konsumsi daun katu dalam jumlah tertentu diduga akan meningkatkan kadar vitamin A dalam air susu dan memperkaya kadar vitamin $\mathrm{C}$ dan mineral terutama zat besi yang akan memberikan stimulasi kepada saraf otak sehingga akan meningkatkan perkembangan sel otak. Perkembangan sel otak yang meningkat akan diikuti dengan perkembangan bayi meliputi motorik halus, kasar, bahasa dan adaptasi sosial. Perkembangan pada masa ini merupakan "golden periode" sehingga perlu diperhatikan nutrisi bagi bayi (Adriana, 2011). Kualitas perkembangan anak harus ditingkatkan sejak dini melalui periode penting yaitu masa bayi karena pada masa ini perkembanganyang terjadi akan mempengaruhi perkembangan selanjutnya, sehingga penyimpangan sekecil apapun harus terdeteksi dan tertangani secara baik agar tidak mengurangi kualitas sumber daya manusia kelak dikemudian hari (Soetjiningsih, 2012). Kuesioner Pra Skrining Perkembangan merupakan suatu daftar pertanyaan singkat yang ditujukan kepada orang tua dan dipergunakan sebagai alat untuk melakukan skrining pendahuluan bagi perkembangan anak (Depkes, 2010). Dengan menggunakan KPSP maka orang tua dapat dengan cepat dan mudah mendeteksi penyimpangan yang terjadi pada bayi sedini mungkin sehingga dapat diberikan tindakan dengan tepat. Pada saat ASI sudah diproduksi, peran hormon oksitosin dibutuhkan. Hormon ini memastikan terjadinya kerutan otot di sekitar saluran susu, menggerakkan susu dari kelenjar susu ke puting sehingga mudah dicapai oleh bayi saat disusui. Produksi ASI memang bisa meningkat dan juga bisa menurun. Sebab jika bayi minum ASI yang banyak maka produksi ASI ibu juga akan banyak. Dan jika bayi meminum ASI sedikit maka produksi ASI ibu juga akan berkurang. Sebab produksi ASI dapat meningkat atau menurun tergantung pada stimulasi kelenjar payudara. Faktor lain yang dapat mempengaruhi produksi ASI adalah frekwensi penyusuan, berat badan bayi, umur kahamilan saat melahirkan, umur ibu, psikologi ibu, nutrisi ibu, gaya hidup, dan penggunaan pil $\mathrm{KB}$, serta konsumsi ektraks daun katu yang di yakini mempunyai kandungan zat yang dapat meningkatkan perkembangan sel otak. Solusi yang dapat dilakukan untuk meningkatkan produksi ASI dengan meningkatkan frekwensi penyusunan, perawatan payudara, perbaikan gizi, hindari stress, hindari alkohol, hindari rokok, dan konsumsi ektrak daun katu yang sudah diproduksi. Peningkatan perkembangan sel otak pada penelitian tikus, perlu dilakukan uji coba kepada manusia, dengan mengidentifikasi perkembangan motorik halus, perkembangan motorik kasar, bahasa dan sosialisasinya. 


\section{METODE}

Jenis penelitian adalah quasi ekperimen dengan rancangan The Post Tes Only Control Group Design, populasi sebesar 24 orang. Populasi Target: seluruh ibu menyusui yang telah mengkonsumsi ekstrak daun katu di kelurahan Wonokromo sebesar 24 orang. Unit analisis : sebagian ibu menyusui yang yang telah mengkonsumsi ekstrak daun katu di kelurahan Wonokromo, sebesar 6 responden masing-masing perlakuan. Variabel bebas yaitu jumlah daun Souropus Androgynus (L.) Merr. Variabel tergantung yaitu kadar prolaktin serum darah ibu menyusui dan perkembangan anak setelah ibu menyusui me4ngkonsumsi ekstraks daun Sauropus Androgynus (L) Merr. Penelitian ini menggunakan metode pengumpulan data primer. Seluruh responden yang ada dibagi menjadi 4 kelompokj, kelompok 1 dengan jumlah konsumsi 3 kali sehari, dan kelompok kedua dengan jumlah 2 kali sehari serta kelompok ketiga dengan jumlah 1 kali sehari, serta kelompok 4 yang tidak mengkonsumsi sebagai kelompok kontrol. Seluruh kelompok diberi ektrak daun katuk selama 3 bulan. Masing-masing responden diambil darahnya untuk dilakukan pemeriksaan hormone prolaktin pada hari ke 30, 60, dan 90. Perkembangan bayi diobservasi pada hari ke 30, 60. dan hari ke 90 meliputi perkembangan motorik halus, kasar, bahasa dan soasial. Tehnik pengumpulan data adalah cara yang digunakan peneliti dalam mengumpulkan data penelitiannya (Arikunto, 2002). Dalam penelitian ini menggunakan metode pengumpulan data primer. Data primer adalah data yang didapatkan langsung dari ibu menyusui dan anak setelah ibu menyusui diberi ektrak daun Sauropus Androgynus (L.) Merr. Data yang dikumpulkan adalah serum darah ibu menyusui untuk menentukan kadar prolaktin. Perkembangan bayi dengan mengobservasi perkembangan motorik kasar, halus, bahasa dan sosial. Data yang diperoleh dianalisa dengan menggunakan tabel distribusi dan dilakukan tabulasi silang antara ibu menyusui yang diberi ekstrak daun Sauropus Androgynus (L.)Merr, dan ibu menyusui sebagai kontrol yang tanpa pemberian ektrak daun katu. Untuk mengetahui adanya perbedaan perlakuan antara ibu menyusui yang diberi i ekstrak daun Sauropus Androgynus (L.) Merr dengan ibu menyusui sebagai kontrol dengan uji Anava satu arah. Syarat yang harus dipenuhi dengan uji Anava adalah kelompok yang dibandingkan terdiri dari dua kelompok, data berdistribusi normal, tidak ada korelasi di antara kelompok perlakuan dan variasinya homogen. Uji One Way Anava yang bermakna secara signifikan akan dilanjutkan uji Post Hoc dengan LSD. Uji tersebut dilakukan untuk mengetahui pada kelompok mana yang berbeda, yaitu antara kelompok kontrol dengan perlakuan dan antara kelompok perlakuan itu sendiri. Perbandingan antar kelompok tersebut dapat menggambarkan perlakuan mana yang berbeda dengan perlakuan yang lain, sehingga dapat diketahui pada dosis berapa ekstrak daun katu dapat menimbulkan efek positif. Mengetahui adanya perbedaan kadar prolaktin antara keempat kelompok (1 kelompok kontrol dan 3 kelompok perlakuan dengan berbeda banyaknya ektrak daun katu) dilakukan uji The Post Test - Only Control Group Designe menggunakan komputer dengan derajat kemaknaan $\alpha=0,05$ artinya $\mathrm{P}$ value lebih kecil daripada $\square$ maka $\mathrm{H}_{1}$ diterima berarti ada perbedaan kadar hormone prolaktin pada ibu menyusui yang mengkonsumsi ektrak daun Sauropus Androgynus. Semua uji statistik dilakukan dengan derajat kepercayaan $95 \%$. Penelitian ini akan dilaksanakan mulai bulan Mei s/d Juni 2015.

\section{HASIL DAN PEMBAHASAN}

Kadar hormon prolaktin 
Kadar hormon prolaktin pada kelompok kontrol dan perlakuan dibagi menjadi normal jika berada $5-25 \mathrm{mg} / \mathrm{ml}$ dan tidak normal $<5 \mathrm{mg} / \mathrm{ml}$ atau $>25 \mathrm{mg} / \mathrm{ml}$. Hasil penetapan kadar prolaktin tersebut dapat dilihat pada tabel 1

Tabel 1 Kadar hormon prolaktin ibu menyusui di Kelurahan Wonokromo Surabaya Tahun 2016

\begin{tabular}{lllll}
\hline Kode & $\mathbf{K}(\mathbf{3 0} \mathbf{h r})$ & $\begin{array}{l}\mathbf{P 1}(\mathbf{3 0} \\
\mathbf{h r})\end{array}$ & $\begin{array}{l}\mathbf{P 2}(\mathbf{6 0} \\
\mathbf{h r})\end{array}$ & $\begin{array}{l}\mathbf{P 3}(\mathbf{9 0} \\
\mathbf{h r})\end{array}$ \\
\hline $\mathbf{1}$ & 6,7 & 7,8 & 10,3 & 19,6 \\
$\mathbf{2}$ & 4,6 & 8,2 & 8,2 & 18,8 \\
$\mathbf{3}$ & 4 & 10,36 & 14,6 & 20,7 \\
$\mathbf{4}$ & 3,8 & 8,4 & 16,3 & 21,2 \\
$\mathbf{5}$ & 7,5 & 10,2 & 12,6 & 7,8 \\
$\mathbf{6}$ & 5,8 & 13,3 & 20,1 & 17,8 \\
Mean & 4,7 & 9,7 & 13.68 & 17,65 \\
$\mathbf{\pm S D}$ & $\mathbf{\pm 1 0 , 2 3 1}$ & $\mathbf{\pm 1 7 1 , 1 7}$ & $\mathbf{\pm 1 0 , 4 6 3}$ & $\mathbf{\pm 8 , 3 5 3}$ \\
\hline
\end{tabular}

Berdasar tabel diatas didapatkan data kadar hormon prolaktin pada kelompok kontrol hari ke 30 adalah hampir setengahnya $(50 \%)$ berada pada kategori tidak normal, kelompok perlakuan pada hari ketiga puluh sebagian besar berada pada kategori normal. Pada hari keenam puluh pada kelompok kontrol hampir seluruhnya berada pada kategori tidak normal, sedangkan pada kelompok perlakuan sebagian besar ada pada kategori normal. Hari kesembilan puluh kelompok kontrol hamper seluruhnya berada pada kategori tidak normal, sedangkan kelompok perlakuan setengahnya berada pada kategori normal.

Tabel 2 Perkembangan Bayi Pada Hari ke 30, 60 dan 90 Setelah mengkonsumsi Daun Katu di Kelurahan Wonokromo Surabaya
Hasil uji normalitas dengan uji Shapiro Wilk di dapatkan nilai $p(0.125)>\alpha(0,05)$ yang artinya data berdistribusi normal. Hasil uji statistic Based on Mean diperoleh signifikansi $p(0,920)>\alpha(0,05)$, maka variansi setiap sampel adalah sama. Hasil uji One Way Anova didapatkan perbedaan yang bermakna $(p=0,000)$. Dilanjutkan uji Post Hoc dengan LSD didapatkan perbedaan yang bermakna pada $\mathrm{K}-\mathrm{P} 1$ (sig) sebesar 0,001, K - P2 (sig) sebesar 0,000, K - P3 (sig) sebesar 0,016.

Perkembangan Bayi Pada Hari ke-30, 60 dan 90 Setelah Mengkonsumsi Ekstrak Daun Katu

\begin{tabular}{|c|c|c|c|c|}
\hline Kode & $\mathbf{K}(\mathbf{3 0} \mathbf{~ h r})$ & $\begin{array}{l}\text { P1(30 hr) } \\
\text { (a) }\end{array}$ & P2(60 hr) & $\begin{array}{l}\mathbf{P 3}(90 \mathrm{hr}) \\
\end{array}$ \\
\hline 1 & 2 & 2 & 3 & 3 \\
\hline 2 & 1 & 1 & 2 & 3 \\
\hline 3 & 1 & 3 & 3 & 2 \\
\hline 4 & 1 & 2 & 3 & 3 \\
\hline 5 & 2 & 3 & 2 & 3 \\
\hline 6 & 1 & 2 & 3 & 3 \\
\hline Mean & 1,3 & 2,2 & 2,7 & 2,8 \\
\hline \pm SD & $\pm 5,477$ & $\pm 6,802$ & $\pm 7,605$ & $\pm 8,060$ \\
\hline
\end{tabular}

Berdasarkan tabel diatas didapatkan data perkembangan bayi pada kelompok kontrol $(1,3)$, perlakuan $1(2,2)$, perlakuan $2(2,7)$, dan perlakuan $3(2,8)$. Hasil uji 
statistik Based on Mean diperoleh signifikansi $p(0,074)>\alpha(0,05)$ maka variansi data sama. Hasil uji One Way Anova di dapatkan perbedaan yang bermakna $(p=0,000)$. Dilanjutkan uji Post Tabel 3 Tabulasi Silang Antara Hormon Prol Wonokromo Surabaya

\begin{tabular}{lllllllll}
\hline Kode & Kontrol & & P1 & & P2 & & P3 & \\
\hline & Prolaktin & $\begin{array}{l}\text { Perkemb } \\
\text { angan } \\
\text { bayi }\end{array}$ & Prolaktin & $\begin{array}{l}\text { Perkembangan } \\
\text { bayi }\end{array}$ & Prolaktin & $\begin{array}{l}\text { Perkembangan } \\
\text { bayi }\end{array}$ & Prolaktin & $\begin{array}{l}\text { Perkembangan } \\
\text { bayi }\end{array}$ \\
1 & 6,7 & 2 & 7,8 & 2 & 10,3 & 3 & 19,6 & 3 \\
2 & 4,6 & 1 & 8,2 & 1 & 8,2 & 2 & 18,8 & 3 \\
3 & 4 & 1 & 10,36 & 3 & 14,6 & 3 & 20,7 & 2 \\
4 & 3,8 & 1 & 8,4 & 2 & 16,3 & 3 & 21,2 & 3 \\
$\mathbf{5}$ & 7,5 & 2 & 10,2 & 3 & 12,6 & 2 & 7,8 & 3 \\
$\mathbf{6}$ & 5,8 & 1 & 13,3 & 2 & 20,1 & 3 & 17,8 & 3 \\
Mean & 4,7 & 1,3 & 9,7 & 2,2 & 13.68 & 2,7 & 17,65 & 2,8 \\
$\mathbf{\pm S D}$ & $\mathbf{\pm 1 0 , 2 3 1}$ & $\mathbf{\pm}, 477$ & $\mathbf{\pm 1 7 1 , 1 7}$ & $\mathbf{\pm} 6,802$ & $\mathbf{\pm 1 0 , 4 6 3}$ & $\mathbf{\pm 7 , 6 0 5}$ & $\mathbf{\pm 8 , 3 5 3}$ & $\mathbf{\pm}, 060$
\end{tabular}

Berdasar tabel diatas dan hasil uji Anava didapat hasil $P=0,001 \leq \alpha(0,05)$ yang berarti ada pengaruh antara konsumsi ektraks daun katu dengan perkembangan bayi di kelurahan Wonokromo Surabaya.

\section{Hormon Prolaktin}

Hasil pemeriksaan hormon prolaktin mempunyai perbedaan yang bermakna antara kelompok kontrol dengan perlakuan 1, 2 dan 3, penyebabnya adalah ektraks daun katu yang dikonsumsi oleh ibu menyusui mempunyai dosis yang berbeda antara kelompok perlakukan 1, 2 dan 3 . Dosis yang diberikan pada perlakuan 1 (1 ektraks x perhari) tidak banyak menempati reseptor prolaktin pada sel laktotrof, sedangkan pada perlakuan 2 (2 Ektraks/x perhari) dan 3 (3 x ektraks perhari) terjadi peningkatan yang bermakna pada perlakuan 2 dan 3, hal ini dikarenakan pemberian ektraks daun katu akan memberikan stimulasi terhadap reseptor prolaktin yang ada pada sel laktotrof sebagai penghasil prolaktin. Peningkatan tersebut terjadi karena dengan pemberian dosis yang tinggi akan menimbulkan stimulus reseptor prolaktin pada sel laktotrof untuk memacu neurohormon yang akan merangsang pengeluaran
Hoc dengan LSD didapatkan perbedaan yang bermakna pada K-P2 (sig) sebesar 0,0000, K-P3 (sig) sebesar 0,0000, P1-P2 (sig) sebesar 0,0000, P1-P3 (sig) sebesar 0,0000, dan P2-P3 (sig) sebesar 0,0000.

rolaktin dengan Perkembangan Bayi di Kelurahan . 
susu, dan akhir kehamilan terjadi penurunan kadar hormon estrogen dan progesteron, serta peningkatan kadar hormon prolaktin dalam tubuh ibu. Kadar ini dibutuhkan oleh prolaktin agar dapat memacu pembentukan air susu oleh kelenjar susu. Hormon perifer, seperti estrogen, hormon tiroid, vitamin D, glukokortikoid merupakan modulator yang sangat poten bagi sintesis prolaktin dan pengekpresikan gen prolaktin. Regulasi terhadap sekresi prolaktin oleh sel laktotrof tampaknya sebagian besar dikontrol oleh keseimbangan antara Prolactin Releasing Factor (PRF) dan Prolactin Inhibiting Factor (PIF) (Linda, 2006). Pendapat dari Yen dan Jaffe mendukung pendapat diatas yang mengatakan bahwa pengaruh estrogen yang bersifat positif terhadap prolaktin turnover pada hipofisa terjadi karena aktivasi dari traskripsi gen dan akumulasi mRNA prolaktin dan estrogen mempunyai sifat antidopaminergik yang akan menyebabkan penurunan kemampuan dopamin. Produksi estrogen oleh plasenta pada masa kehamilan tergantung kepada prekursor yang beredar di dalam darah, dimana steroid yang berasal dari ibu menyusui sumber terpenting (Martin, Hoffman, 1983). Selama kehamilan terjadi peningkatan kadar hormon estrogen dalam serum, estron dan estriol meningkat sebanyak 50 kali kadar sebelum kehamilan sedangkan estradiol 1000 kali.

\section{Perkembangan bayi}

Hasil pemeriksaan perkembangan bayi antara kelompok kontrol dengan perlakuan 2 dan 3, dan antara perlakuan 1 dengan perlakuan 2 dan 3, serta antara perlakuan 2 dan 3. Hormon prolaktin yang baik akan berpengaruh terhadap perkembangan pada bayi utamanya adalah jumlah perkembangan sel syaraf. Pemberian ekstrak daun katu pada dosis yang lebih tinggi (perlakuan 2 dan 3) akan memberikan stimulasi pada perkembangan sel otak. Pengeluaran tersebut juga didukung dengan kualitas dan kuantitas rangsangan, selama perlakuan ibu dalam kondisi lingkungan yang nyaman dan sebagian besar ibu mempunyai pengalaman untuk memberikan stimulasi terhadap motorik halus, motorik kasar, bahasa dan sosial pada bayi. Stimulasi yang baik kepada bayi akan mempengaruhi rangsangan pada reseptor perkembangan sehingga akan memberikan perkembangan yang baik. Makanan minuman yang dikonsumsi oleh ibu menyusui juga akan berpengaruh kepada perkembangan bayi. Responden pada penelitian ini membuktikan bahwa sebagian besar ibu menyusui terhindar dari stress. Faktor psikologi sejak lama diketahui sebagai penyebab hambatan pengeluaran air susu ibu. Gangguan emosi dan kecemasan dapat menyebabkan gangguan terhadap hormon prolaktin, faktor lain yang mempengaruhi hormon prolaktin adalah isapan dari bayi, semakin lama dan semakin sering bayi menyusui maka semakin banyak air susu diproduksi. Semakin baik hormon prolaktin dan nutrisi dari ibu menyusui yang mengkonsumsi ektrak daun katu (yang diyakini mempunyai kandungan gizi yang baik) maka semakin baik kualitas dan kuantitas air susu yang dikonsumsi oleh bayi. Pendapat Kamariyah (2012), mendukung alasan diatas bahwa air susu yang dihasilkan seorang ibu bervariasi, baik kualitas maupun kuantitasnya. Faktorfaktor yang mempengaruhinya antara lain adalah psikologi, fisiologi dan sosiologi. Faktor psikologi sejak lama diketatahui sebagai penyebab hambatan pengeluaran air susu ibu. Gangguan emosi dan kecemasan dapat menyebabkan gangguan terhadap "let down reflex", yaitu suatu refleks yang berperan pada pengeluaran air susu dari kelenjar susu. Faktor fisiologi mempengaruhi jumlah air susu, yaitu pengaruh pada kemampuan mensekresi dan mengeluarkan air susu. Frekuensi dan lama waktu menyusui serta besarnya rangsangan pada puting susu mempengaruhi jumlah air susu yang 
disekresi dan dikeluarkan dari kelenjar susu. Pendapat diatas didukung pendapat dari Kamariyah (2012). Pembentukan air susu di kelenjar susu terjadi di dalam sel alveoli dan kemudian dialirkan ke dalam lumen. Proses itu meliputi pengambilan prekursor dari dalam darah yang selanjutnya dialirkan menuju sel. Air susu yang sudah terbentuk dapat tersimpan di dalam alveoli, duktus dan sinus kelenjar. Mekanisme pengeluarannya terjadi setelah kelenjar susu memperoleh rangsangan. Ada dua jenis rangsangan yang dapat menyebabkan pengeluaran air susu, yaitu rangsangan fisik dan psikis. Rangsangan fisik antara lain dapat berupa hisapan pada puting susu atau manipulasi kelenjar susu, sedangkan rangsangan psikis dapat berupa rangsangan yang diasosiasikan dengan manipulasi kelenjar susu, seperti tangis atau keinginan untuk menyusui. Rangsangan fisik atau eksternal dalam bentuk hisapan bayi pada puting susu akan melewati alur tertentu yang secara anatomis mempunyai pola yang sama, baik pada binatang coba maupun pada manusia. Oksitosin merangsang kontraksi sel-sel miopitel yang mengelilingi alveoli dan kontraksi itu menyebabkan air susu di dalam alveoli terperas masuk kedalam duktus yang lebih besar. Peningkatan tekanan akan yang terjadi secara refleks, yang memungkinkan air susu mengalir keluar melalui puting susu. Refleks itu disebut "let down refleks. Bayi yang menyusu tidak akan memperoleh air susu secara langsung, tetapi harus menunggu lebih kurang satu setengah menit sebelum air susu mengalir keluar. Air susu tidak dapat keluar walaupun susu terisi penuh apabila tanpa "let down refleks". Meningkatnya produksi air susu induk dan nutrisi yang baik akan meningkatkan kandungan gizi dari air susu. Daun Sauropus androgynus (L). Merr mempunyai kandungan gizi yang baik, seperti kandungan protein, vitamin $\mathrm{A}, \mathrm{C}$, Zat besi, lemak dan sterol yang merupakan bahan dasar perkembangan sel neuralgia, sehingga jika dikonsumsi oleh ibu menyusui akan memberikan pengaruh baik kepada anak. Pengaruh yang dapat dilihat adalah perkembangan otak anak khususnya sel neuraglia. Sel neuraglia mengandung berbagai macam sel yang secara keseluruhan menyokong, melindungi, dan sebagai sumber nutrisi sel saraf pada otak dan medulla spinalis, perkembangan sel neuroglia yang baik akan terlihat pada perkembangan bayi diantaranya perkembangan motorik halus, perkembangan motorik kasar, sosial dan bahasa. Terbukti pada hasil penelitian menunjukkan perkembangan yang bermakna pada 4 komponen perkembangan yang di dapat semakin baik maka semakin baik pula kecerdasannya. Kecerdasan anak, tentu tidak terlepas dari awal pembentukan berbagai alat dan organ vital bayi sejak dalam kandungan induknya. Ada dua macam kritis tumbuh kembang dengan masing-masing konsekuensinya terhadap bayi dan kandungan. Masa kritis pertama berlangsung sejak dalam kandungan, yang dimulai dengan pembentukan berbagai organ vital, sistem saraf pusat dan otak, jantung, pancaindra, alat kelamin, dan lainnya. Gangguan pada masa ini jika terjadi maka anak akan berisiko tinggi menderita gangguan morfologi pada berbagai alat vital saat lahir hingga dewasa. Masa kritis kedua berlangsung saat kelahiran. Masa ini merupakan periode penyempurnaan proses tumbuh kembang organ tubuh yang telah dibentuk pada periode sebelumnya. Gangguan jika terjadi pada saat ini, anak berisiko menderita gejala kelainan fisiologis sejak lahir dan semakin parah saat dewasa nanti. Masa kritis tersebut jika terjadi, maka anak sangat memerlukan baragam zat gizi guna mendukung proses tumbuh kembang yang optimal utamanya perkembangan otak untuk mendukung kecerdasannya. Kandungan senyawa terpenoid (sterol) yang ada pada daun Sauropus Androgynus (L). Merr akan mudah masuk kedalam otak bayi setelah bayi menyusu pada 
ibunya, hal ini dikarenakan sterol tersebut mempunyai sifat lipid sehingga mudah masuk kedalam otak yang akan mempengaruhi perkembangan sel neuraglia. Sistem saraf pusat dan otak merupakan organ vital yang pertama dibentuk. Proses pertumbuhan sel neuron otak terjadi pada saat kehamilan dan disempurnakan hingga bayi berusia dua tahun. Meskipun massa otak anak hanya sekitar $16 \%$ dari tubuhnya, namun dibandingkan dengan organ tubuh lain, otak paling banyak memerlukan energi (lebih dari $70 \%$ ) untuk proses tumbuh kembangnya. Energi itu terutama berasal dari deposit zat gizi dan asam lemak esensial tubuh induknya.

\section{Tabulasi silang antara hormon prolaktin dengan perkembangan bayi}

Hormon prolaktin ibu menyusui tidak ada hubungan terhadap perkembangan bayi. Perkembangan bayi dipengaruhi oleh banyak faktor, diantaranya dipengaruhi oleh kuantitas dan kualitas isapan bayi, semakin baik kuantitas dan kualitas isapan bayi semakin baik pula terjadinya perkembangan bayi. Faktor lain adalah nutrisi ibu mneyusui, semakin baik nutrisi ibu menyusui semakin baik pula terjadinya perkembangan bayi. Daun katu mempunyai kandungan gizi yang baik seperti kandungan vitamin A, lemak, protein dan sterol yang merupakan bahan dasar perkembangan sel pelindung otak. Hormon prolaktin sangat berhubungan dengan hormon prolaktin, dan hormon prolaktin sangat berhubungan dengan perkembangan sel neuraglia. Hormon prolaktin yang tinggi tidak akan memhormon prolaktin jika tidak ada isapan dari bayi, isapan bayi yang baik dan didukung dengan nutrisi ibu akan sangat berpengaruh kepada perkembangan jumlah sel neuraglia. Pendapat diatas didukung dengan teori dari Rusli 2001 yang mengatakan bahwa prolaktin merangsang kelenjar susu untuk memproduksi ASI, sedangkan rangsangan pengeluaran prolaktin ini adalah pengosongan ASI dari gudang ASI (Sinus Lactiferus). Semakin banyak ASI yang dikeluarkan dari payudara maka semakin banyak ASI yang diproduksi, sebaliknya apabila bayi berhenti menghisap atau sama sekali tidak memulainya, maka payudara akan berhenti memproduksi ASI. Setiap isapan bayi pada payudara ibunya akan merangsang ujung saraf di sekitar payudara. Rangsangan ini diantar ke bagian depan kelenjar hipofise untuk memproduksi prolaktin. Prolaktin dialirkan oleh darah ke kelenjar payudara dan akan merangsang pembuatan ASI. Kejadian dari perangsangan payudara sampai pembuatan ASI disebut reflex produksi ASI atau reflek prolaktin, semakin jarang ibu menyusui, maka semakin berkurang jumlah produksi ASI-nya (Rusli, 2001). Bayi tidak akan mendapatkan ASI cukup apabila hanya mengandalkan reflek prolaktin saja, dan harus dibantu oleh reflek oksitosin. Reflek tersebut jika tidak bekerja, maka bayi tidak akan mendapatkan ASI yang memadai, walaupun produksi ASI cukup. Reflek oksitosin lebih rumit dibandingkan reflek prolaktin, karena reflek ini berhubungan langsung dengan kejiwaan atau sensasi ibu. Perasaan ibu dapat meningkatkan dan menghambat produksi ASI (Rusli, 2001). Bayi mendapat sumber DHA dari ASI. Memberikan ASI kepada bayi telah terbukti secara ilmiah dapat meningkatkan kecerdasan anak karena salah satu nutrisi kunci yang berguna untuk meningkatkan kecerdasan adalah DHA yang terdapat dalam ASI. Dalam perkembangan otak bayi lebih mengutamakan zat AA dan DHA seperti yang terdapat dalam ASI. Kandungan gizi daun katu akan mengaktifkan pengikatan reseptor sel saraf, meningkatkan permeabilitas sel dan ion, meningkatkan aktifitas enzim, meningkatkan inisiasi dan transmisi impuls saraf sehingga mempengaruhi perkembangan sel neuraglia, yang akan menunjukkan tingkat kecerdasan. Pada bayi tingkat kecerdasan dapat di lihat pada 
komponen perkembangan yang meliputi motorik halus, motorik kasar, adaptasi sosial dan kemampuan berbahasa.

\section{SIMPULAN}

1. Hormon prolaktin ibu mneyusui setelah mengkonsumsi ektrak daun Sauropus androgynus, (L.). Merr (Katu) mempunyai pengaruh yang bermakna pada dosis $2 \mathrm{x}$ perhari dan $3 \mathrm{x}$ perhari pada ibu di kelurahan Wonokromo Surabaya

2. Perkembangan bayi setelah ibu menyusui mengkonsumsi ektrak daun katu (Sauropus androgynus,) (L.). Merr (Katu) mempunyai pengaruh yang bermakna pada dosis $2 \mathrm{x}$ sehari dan 3 x sehari pada ibu di kelurahan Wonokromo Surabaya.

3. Peningkatan hormon prolaktin ibu menyusui tidak ada pengaruh dengan peningkatan perkembangan bayi di kelurahan Wonokromo Surabaya

\section{DAFTAR PUSTAKA}

Adriana, Dian. (2011). Tumbuh Kembang dan Terapi bermain pada anak. Jakarta: Salemba Medika.

Bilash T, (2003) : Estrogen, Gender and Aging effect on Central Nervous System Physiology. http://www.drtimdeliver.com/E2. Aging0910003.shtml. Diakses 3 Januari 2011

Byrnes E M, Bridges $\mathrm{R} S$, (2005): Lactation reduces prolaktin levels in reproductively ekperienced female rats, hormones and behavior.

http://www.scienedirect.com/sdie nce?ObarticleURL\&ufdiB6WG C4G3KCO7-

8\&-user. Diakses tanggal 2

Januari 2011.

Chatterton R T, Hill P D (2000) : Relation of plasma Oxytocin and Prolaktin Consentration to milk production in mother of preterm infants : Influence of
Stress; J.C.E.M. http://jcem.endojournal.org/cgi/c ontent/full/85/10/3661. Diakses 25 Desember 2010

Davis M, (2000) Anatonybof the breast, how the breast. Makes milk.

http://www.lactationconsultant.inf o/how.html. Diakses tanggal 28 Januari 2011

Departemen Kesehatan RI, (2012). Daftar komposisi bahan makanan. Pusat penelitian gizi. Bogor.

Departemen Kesehatan RI. (2010).

Parameter standart umum ekstrak tumbuhan obat. Cetakan pertama. Direktorat Jendral Pengawasan Obat dan Makanan. Jakarta.

Dep Kes RI, (2005). Pedoman Deteksi Kelainan dan Stimulasi Dini Tumbuh Kembang

Balita. Jakarta.

DepKes RI, (2010). Instrumen Deteksi Dini Penyimpangan Perkembangan pada

Balita dan Anak Prasekolah. Jakarta:

Gritter RJ, Bobbitt JM, Schwarting AE, (2007). Pengantar Kromatografi. Edisi kedua, Bandung : Percetakan ITB

Hamilton WJ, (1976). Female reproductive organs. In Textbook of Human

Anatomy, $2^{\text {nd }}$ edition. The Mac Millan Press Ltd.,. London

Kamariyah N, (2012) : Pengaruh ektrak daun katu terhadap peningkatan kadar hormone prolaktin tikus menyusui dan perkembangan sel neuralgia anak tikus. Tesis program pasca sarjana Universitas Airlangga Surabaya

Pidada, I.B.Rai. (2002). Perbandingan pengaruh pemberian infus daun katu 
(Sauropus Androgynus (L.). Merr dan daun Lampes (Ocimum sanctumlinn) terhadap peningkatan berat badan dan jumlah alveolus kelenjar ambing pada tikus. http//adln.lib.unair.ac.id/go.php? id = jiptunair-gdl.1999 pidada2c-325a alveolus \& PHPSESSID = ccd4ffb385ea28aac4bddf284B5D 548. Diakses tanggal 1 Januari 2011.

Mangestuti, A. (1997). Isolasi zat kandungan aktif daun sauropus androgynus (L.) Merr. Yang berkhasiat laktagogum. Disertasi. Program pasca sarjana Universitas Airlangga Surabaya.

Martina D.N. (2007) . Isolasi kandungan senyawa daun Sauropuis laktagogum daun Sauropus Androgynus (L.) Merr. Skripsi : Fakultas Farmasi Universitas Airlangga. Surabaya

NSW, (2003) Health-Brest feeding : Best for babies and mother. Publikasi pdfs/DOHs/7595/.DOH7495IND Best for babies and mother. .pdf. Diakses tanggal 24 November

Martinez, M. and A. Ballabriga. 1987. Effects of parentheral nutrion with high doses of linoleate on the developing human liver and brain.

Nugraheni, Noor. W. Uji 2009. Uji toksitas akut ekstrak valerian (valeriana officinalis) terhadap otak tikus Balb/c. (jurnal) staf pengajar bagian farmakologi Fakultas Kedokteran Universitas Diponegoro.

Reza A, (2007). Isolasi kandungan senyawa daun Sauropus Androgynus (L) Mer.Skripsi : Fakultas Farmasi Universitas Airlangga. Surabaya
Santoso, U. (2000). Mengenal daun

katu sebagai feed additive pada broiler. Poultry Indonesia.

Santoso, U. (20001a). Effect of Sauropus androgynus extract on the carcass quality of broiler chicks. B I P P,

Santoso, U. (20001b). Effect of Sauropus androgynus extract on the performance of broiler. B I P P,

Santoso, U. (2001c). Effect of Sauropus androgynus extract on organ weight, toxicity and number of Salmonella sp and Escherichia coli of broiler meat. B I P P,

Santoso, U. (2002). Aplikasi Teknologi

Ekstrak Daun Katu pada Broiler. Public Service. Bengkulu University, Bengkulu.

Santoso, U and Sartini. (2001). Reduction of fat accumulation in broiler chickens by Sauropus androgynus (Katu) leaf meal supplementation. AsianAust. J. Anim.

Santoso, U., Suharyanto, E. Handayani. (2001). Effects of Sauropus androgynus (Katu) leaf extract on growth, fat accumulation and fecal microorganisms in broiler chickens. J I T V.

Santoso, U., J. Setianto, T. Suteky. $\left(2002^{\circ}\right)$. Penggunaan Ekstrak Daun Katu

Untuk Meningkatkan Efisiensi

Produksi dan Kualitas Telur

yang Ramah

Lingkungan pada Ayam

Petelur. Research Report,

Bengkulu

University,Bengkulu.

Santoso, U., T. Suteky, Heryanto, Sunarti. (2002b). Pengaruh cara pemberian ekstrak daun katu (Sauropus androgynus) 
terhadap penampilan dan kualitas karkas ayam pedaging.

Saparinah Sadli (2005) : Kesehatan Reproduksi perempuan dan hak asasi manusia: dalam bunga rampai obstetri dan ginekologi sosial, YBP-SP.

Sekartini, (2013). "Stimulasi Perkembangan otak balita". http:catchcoalition.ca/trellis/learning_abo ut_the_brain. Artikel diakses tanggal 1 Juli 2014. Jam 07.05 WIB.

Subekti, S. (2003). Kualitas telur dan karkas ayam lokal yang diberi tepung daun katu dalam ransum. PPS IPB, Bogor.

Suprayogi, A. (2000). Studies on the biological effect of Sauropus androgynus (L) Merr.: Effects on milk production and the possibilities of induced pulmonary disorder in lactating sheep. George-August, Universitat Gottingen Institut fur Tierphysiologie und Tierernahrung.

Suryohudoyo P, (2000) : Mekanisme molekuler aktifitas hormon; kapita selekta ilmu kedokteran molekuler; CV Sagung Seto, Jakarta 